Ann. Biol. anim. Bioch. Biophys., 1978, 18 (1), 157-166.

\title{
Mineral bone composition and some elements of calcium metabolism in magnesium-deficient growing rats
}

par Y. RAYSSIGUIER, P. LARVOR

Laboratoire des Maladies métaboliques, I.N.R.A.

Soint Genès-Champanelle, Theix,

63110 Beaumont, France.

\begin{abstract}
Summary. (1) Magnesium deficiency was induced in Sprague-Dawley male rats studied with pair-fed controls. The animals were killed after 10,22 or 30 days of treatment. (2) The plasma composition of deficient subjects was characterized by : hypomagnesemia, slight hypercalcemia, hypophosphatemia, normal glycemia. Urinary hydroxyprolin decreased in deficient subjects after 21 and 29 days of deprivation. (3) The leg bones were fragmented as shown in figure 1 . Their magnesium content had decreased considerably and they were heavier. These two changes were especially marked in the metaphysis, were moderate in the epiphysis and less in the diaphysis. (4) Changes in the composition of some tissues and the entire body are described. (5) Lower bone catabolism seemed to be mainly related to lower bone magnesium, and not to plasma magnesium. Increase in bone weight appeared to be a result of lower catabolism. The interpretation of calcic metabolism changes is discussed.
\end{abstract}

\section{Introduction.}

Magnesium deficiency induces bone changes for two reasons : bone is the main magnesium store of the organism, and calcium metabolism is impaired in magnesiumdepleted animals.

The decrease of bone magnesium during deficiency has often been reported since Orent, Kruse and McCollum (1934) and Watchorn and Mc Cance (1937). The kinetics of bone magnesium drop was described in calf (Smith, 1959) and in rat (Forbes, 1964). It was also shown that older animals have a slower decrease in bone magnesium (Smith and Field, 1963), however acute the deficiency may be (Hunt, 1971). The depletion of the skeleton in hypomagnesemic calves is not uniform, occurring more rapidly in more vascular bone (Smith, 1959), but there are no data on the kinetics of magnesium depletion at different points in various bones.

The depletion of bone magnesium store is not the only skeletal effect of magnesium deficiency ; in rats 35-S-mucopolysaccharide and protein syntheses are reduced (Belanger, 1958). In calves, bone calcium accretion and bone calcium catabolism both drop sharply (Larvor, Girard and Brochart, 1964) ; in Mg-deficient rat, bone catabolism also seems to be impaired, as evidenced by a reduction in urinary hydroxyprolin (MacManus and Heaton, 1969). Similar results have not been found in $\mathrm{Mg}$ - 
deficient sheep by Hjerpe (1968), but this induced deficiency was probably too slight and radiocalcium estimation of metabolism of too brief a duration.

The decrease of $\mathrm{Mg}$ concentration in the incubation medium in vitro modified bone metabolism ; fetal rat bone resorption was reduced (Raisz and Nieman, 1969), newborn mice calvaria resorption also declined with increased accretion (Nielsen, 1973), and she€p cartilage calcification was impaired (Cartier and Picard, 1955). The physical solubility of bovine bone minerals increased slightly with magnesium medium concentration in the physiological range (Pak and Diller, 1969). However, even in a normal magnesium medium, the bones of $\mathrm{Mg}$-deficient rats released less calcium, phosphorus or hydroxyprolin than control bones from normal animals (Mac Manus, Heaton and Lucas, 1971). In the present paper, we investigate changes occurring in different parts of the bones during magnesium deficiency.

\section{Material and methods.}

Animals. Thirty-six Sprague-Dawley male rats, weighing initially $115 \pm 1.5 \mathrm{~g}$ were randomly divided into 6 groups of six animals and placed in individual wire cages.

Diet. A semi-synthetic diet (Larvor and Labat, 1978) with a low magnesium content ( $40 \mathrm{mg} / \mathrm{kg}$ estimated by analysis) was given to 3 groups of rats ; the other 3 groups
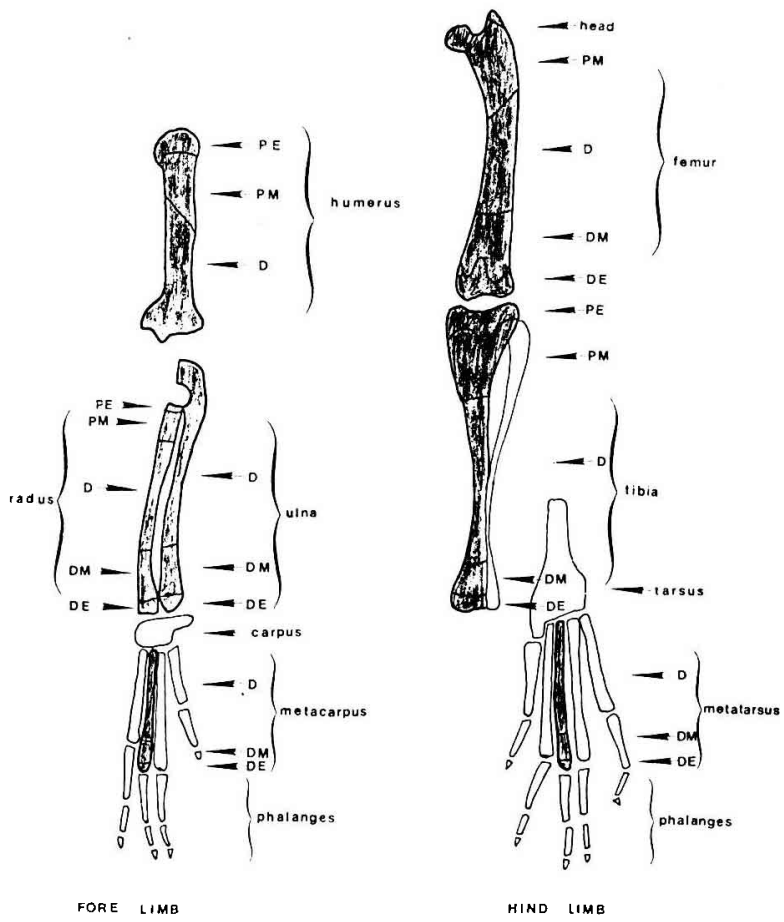

FIG. 1. - Diagram of rat limb bones, showing the general whole bone piece and the analysed parts (shaded area). PE : proximal epiphysis ; PM : proximal metaphysis ; D : diaphysis ; DM : distal metaphysis ; DE : distal epiphysis. 
were pair-fed individually with the same diet supplemented with $1000 \mathrm{mg} / \mathrm{kg} \mathrm{Mg}$. Both diets contained $6500 \mathrm{mg} / \mathrm{kg}$ calcium and $5500 \mathrm{mg} / \mathrm{kg}$ phosphorus.

Experimental procedure. One deficient and one control group were killed at 10, 22 and 30 days after the beginning of treatment. Two days before the end of the period, the rats were placed for one day in a metabolism ccge to obtain 24-hr. urine collection. One day before the end of the period, $1 \mathrm{ml}$ of blood was collected into a heparinized syringe by cardiac puncture under light ether anesthesia. Blood was immediately centrifuged and analysed for magnesium, calcium, inorganic phosphate and glucose. On the last day, the rats were killed with ether, and the limbs of the left side removed and stripped of soft tissue in order to obtain the bones for analytical study.

The bones were cut to separate the epiphyse, metaphyse and diaphyse ; the medulla was washed out and the pieces defatted in acetone, dried, weighed and ashed overnight at $550^{\circ} \mathrm{C}$ in a nickel crucible. The ash was dissolved in dilute $\mathrm{HCl}$ and the solution analysed for $\mathrm{Ca}, \mathrm{P}$ and $\mathrm{Mg}$. Bone fragmentation was carried out according to the diagram in figure 1 .

Analyfical procedure. Urine was analysed for hydroxyprolin using the method described by Bergman and Loxley (1963) adapted to the Technicon Auto-Analyzer. Calcium and magnesium were estimated in blood plasma and in bone by atomic absorption spectrophotometry. Phosphorus was estimated in blood plasma and in bone with a colorimetric method using the molybdic acid reaction, and glucose was determined with an automated glucose oxydase technique (Michel, 1971).

\section{Results.}

Clinical signs. Classical magnesium deficiency symptoms were observed. Hyperemia of the ears appeared some 4 days after the beginning of the experiment and

\section{TABLE 1}

Effect of magnesium deficiency on growth

(control and deficient animals are pair-fed ; during the last 10 days, there is a drop in Mg-deficient rat appetite).

$(\bar{x} \pm \sigma / \sqrt{ } N, *$ Means $P<0.05, * *$ means $P<0.01)$

\begin{tabular}{ccccc}
\hline \multirow{2}{*}{$\begin{array}{c}\text { Length of treatment } \\
\text { (days) }\end{array}$} & \multicolumn{2}{c}{$\begin{array}{c}\text { Bodyweight (grams) } \\
\text { between parentheses, } \\
\text { number of animals }\end{array}$} & \multicolumn{2}{c}{$\begin{array}{c}\text { Mean daily weight gain } \\
\text { (grams) }\end{array}$} \\
\cline { 2 - 6 } & Controls & Deficients & Controls & Deficients \\
\hline 0 & $\begin{array}{c}115.2 \pm 1.6 \\
(18)\end{array}$ & $\begin{array}{c}115.6 \pm 1.4 \\
(18)\end{array}$ & - & - \\
\hline 9 & $\begin{array}{c}134.1 \pm 1.5 \\
(18)\end{array}$ & $\begin{array}{c}137.8 \pm 1.4 \\
(18)\end{array}$ & 2.10 & 2.46 \\
\hline 19 & $\begin{array}{c}188.3 \pm 3.2 \\
(6)\end{array}$ & $\begin{array}{c}176.8 \pm 3.3 \\
(6)\end{array}$ & 5.42 & 3.90 \\
\hline 29 & $\begin{array}{c}199.2 \pm 2.1 \\
(6)\end{array}$ & $\begin{array}{c}178.5 \pm 1.6 * * \\
(6)\end{array}$ & 1.09 & 0.17 \\
\hline
\end{tabular}


disappeared progressively. Increased excitability and delayed growth were noted as compared to the pair-fed controls (table 1).

Blood and urine compositions (table 2). A sharp drop in blood plasma Mg was seen in Mg-deficient animals together with a slight hypercalcemia (significant only at 21 days, $\mathrm{P}<0.05$ ) and a more marked hypophosphatemia. Blood glucose was not significantly affected. Daily urinary hydroxyprolin, practically normal in $\mathrm{Mg}$ deficient animals at 9 days, significantly $(P<0.01)$ decreased at 21 and 23 days. Urinary hydroxyprolin decreased also, but more slowly with increasing age in the controls (table 2).

TABLE 2

Effect of $\mathrm{Mg}$ deficiency on mineral plasma composition and urinary hydroxyprolin $(\bar{x} \pm \sigma / \sqrt{N}, *$ means $P<0.05 ; * *$ means $P<0.01)$

\begin{tabular}{|c|c|c|c|c|c|c|}
\hline \multirow{2}{*}{$\begin{array}{l}\text { Length of } \\
\text { treatment } \\
\text { (days) }\end{array}$} & \multirow{2}{*}{ Treatment } & \multicolumn{4}{|c|}{ Blood plasma concentration $\mathrm{mg} / 100 \mathrm{ml}$} & \multirow{2}{*}{$\begin{array}{c}\text { Urine } \\
\text { hydroxyprolin } \\
\text { (mg/day) }\end{array}$} \\
\hline & & $\mathrm{Mg}$ & $\mathrm{Ca}$ & Inorganic $P$ & Glucose & \\
\hline 0 & Control & $1.72 \pm 0.04$ & $10.0 \pm 0.3$ & $7.7 \pm 0.4$ & $174.5 \pm 5.6$ & not measured \\
\hline \multirow{2}{*}{9} & Control .... & $1.64 \pm 0.04$ & $9.7 \pm 0.3$ & $9.6 \pm 0.4$ & $205.7 \pm 17.4$ & $0.46 \pm 0.04$ \\
\hline & Mg-deficient ... & $0.76 \pm 0.05 * *$ & $10.5 \pm 0.3$ & $8.8 \pm 0.5$ & $218.7 \pm 17.5$ & $0.43 \pm 0.03$ \\
\hline \multirow{2}{*}{21} & Control .... & $1.83 \pm 0.04$ & $9.7 \pm 0.1$ & $7.5 \pm 0.4$ & $169.3 \pm 5.0$ & $0.38 \pm 0.03$ \\
\hline & Mg-deficient ... & $0.51 \pm 0.05 * *$ & $10.5 \pm 0.2 *$ & $5.8 \pm 0.4$ & $169.5 \pm 6.6$ & $0.25 \pm 0.02 * *$ \\
\hline \multirow{2}{*}{29} & Control & $1.90 \pm 0.04$ & $10.7 \pm 0.3$ & $11.0 \pm 0.3$ & $171.5 \pm 5.6$ & $0.32 \pm 0.03$ \\
\hline & Mg-deficient & $0.40 \pm 0.04 * *$ & $10.1 \pm 0.3$ & $7.4 \pm 0.2 * *$ & $166.7 \pm 7.2$ & $0.22 \pm 0.01 * *$ \\
\hline
\end{tabular}

Bone weight. The weight of each bone (table 3) of both limbs slightly increased after 10-day deficiency; it increased considerably after 22 days, although the body weight was then slightly lower in Mg-deficient rats ; it later returned to normal at 30 days, when the body weight of those animals was significantly lower. If bone weight is detailed by fragment (fig. 2), it becomes evident that the diaphysis is the least affected by weight increase during the first part of $\mathrm{Mg}$ deficiency, and that metaphysis is generally the most affected.

Bone composition. Figure 3 shows the $\mathrm{Mg}$ ratio between deficient and normal bone in various parts of the skeleton. There was not much difference between bones as to overall percentage of $\mathrm{Mg}$ depletion, but within the same bone, melaphysis depletion was greater than diaphysis depletion. Moreover, the quantity of $\mathrm{Mg}$ available from bone decreased during $\mathrm{Mg}$ deficiency from the first decade to the third (fig. 4 ; also see section on Gross body composition). Detailed results on $\mathrm{Ca}$ and $\mathrm{P}$ contents in different bone sites are not given here because there are too many data, but they are available from the authors on request. There is a non-significant tendency to bone 


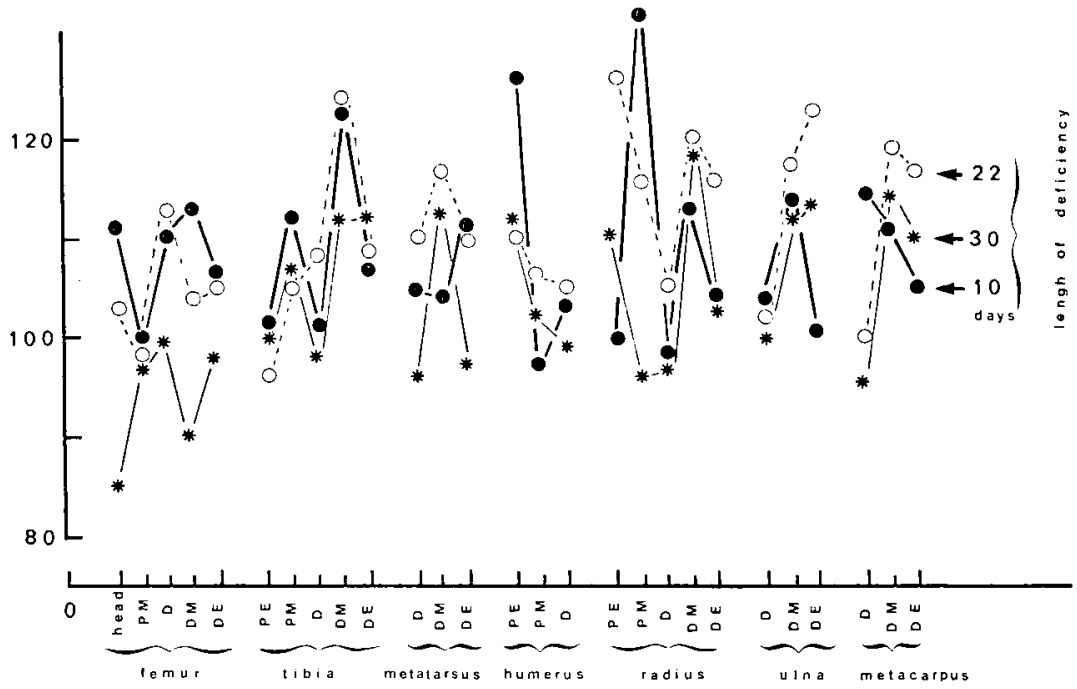

FIG. 2. - Weight of various parts of limb bones in magnesium-deficient animals ; level expressed in p. 100 of controls (see fig. 1 for the diagram of bone pieces)

TABLE 3

Total weight of each bone ( $\mathrm{mg}$ of dry defatted tissue) and mean $\mathrm{Mg}$ content for the total osseous tissue dosed $\left(x \pm \sigma / \sqrt{ } N\right.$, * means $P<0.05 ;{ }^{* *}$ means $\left.P<0.01\right)$

\begin{tabular}{|c|c|c|c|c|c|c|c|c|c|}
\hline \multirow{2}{*}{$\begin{array}{l}\text { Length of } \\
\text { treatment } \\
\text { (days) }\end{array}$} & \multirow{2}{*}{ Treatment } & \multicolumn{7}{|c|}{ Total weight of each bone ( $\mathrm{mg}$, dry defatted) } & \multirow{2}{*}{$\begin{array}{l}\text { Mean Mg of } \\
\text { total limbs } \\
\text { bones } \\
\text { (p. } 1000)\end{array}$} \\
\hline & & Femur & Tibia & Metatars & Humerus & Radius & Ulna & Metacarp & \\
\hline \multirow{2}{*}{10} & Control. . & $\left|\begin{array}{c}211.1 \\
\pm 5.2\end{array}\right|$ & $\begin{array}{l}167.5 \\
\pm 4.2\end{array}$ & $\begin{array}{l}20.3 \\
\pm 0.5\end{array}$ & $\begin{array}{l}111.1 \\
\pm 2.5\end{array}$ & $\begin{array}{l}37.3 \\
\pm 1.4\end{array}$ & $\begin{array}{l}56.5 \\
\pm 1.7\end{array}$ & $\begin{array}{l}7.9 \\
\pm 0.4\end{array}$ & $\begin{array}{l}4.18 \\
\pm 0.04\end{array}$ \\
\hline & Mg-deficient. . & $\begin{array}{r}227.5^{*} \\
\pm 4.8\end{array}$ & $\begin{array}{l}177.3 \\
\pm 4.7\end{array}$ & $\begin{array}{l}21 . \overline{4} \\
\pm 0.6\end{array}$ & $\begin{array}{l}118.0 \\
\pm 2.8\end{array}$ & $\begin{array}{l}39.2 \\
\pm 0.9\end{array}$ & $\begin{array}{l}59.3 \\
\pm 2.0\end{array}$ & $\begin{array}{c}8.7 \\
\pm 0.9\end{array}$ & $\begin{array}{l}3.03 * * \\
\pm 0.08\end{array}$ \\
\hline \multirow{2}{*}{22} & Control. . & $\begin{array}{c}277.3 \\
\pm 6.8 \\
\end{array}$ & $\begin{array}{r}211.2 \\
\pm 3.6 \\
\end{array}$ & $\begin{array}{l}24.6 \\
\pm 0.7\end{array}$ & $\begin{array}{r}138.8 \\
\pm 3.2 \\
\end{array}$ & $\begin{array}{l}44.4 \\
\pm 1.2\end{array}$ & $\begin{array}{l}67.7 \\
\pm 1.2 \\
\end{array}$ & $\begin{array}{c}8.8 \\
\pm 0.3\end{array}$ & $\begin{array}{l}4.45 \\
\pm 0.12 \\
\end{array}$ \\
\hline & Mg-deficient.... & $\begin{array}{c}293.7 \\
\pm 5.9\end{array}$ & $\begin{array}{c}224.3^{*} \\
\pm 3.8\end{array}$ & $\begin{array}{c}27.5 * * \\
\pm 0.6\end{array}$ & $\begin{array}{l}147.0 \\
\pm 2.2\end{array}$ & $\begin{array}{l}49.2 * * \\
\pm 0.9\end{array}$ & $\begin{array}{l}72.0^{*} \\
\pm 1.4\end{array}$ & $\begin{array}{l}10.5 * \\
\pm 0.7\end{array}$ & $\begin{array}{l}2.19 * * \\
\pm 0.10\end{array}$ \\
\hline \multirow{2}{*}{30} & Control. & $\begin{array}{l}330.1 \\
\pm 8.5\end{array}$ & $\begin{array}{l}250.0 \\
\pm 6.4\end{array}$ & $\begin{array}{l}28.9 \\
\pm 0.8\end{array}$ & $\begin{array}{l}163.0 \\
\pm 3.7\end{array}$ & $\begin{array}{l}52.0 \\
\pm 1.3\end{array}$ & $\begin{array}{l}79.3 \\
\pm 2.0\end{array}$ & $\begin{array}{l}10.1 \\
\pm 0.3\end{array}$ & $\begin{array}{l}4.59 \\
\pm 0.08\end{array}$ \\
\hline & Mg-deficient. . & $\begin{array}{c}317.2 \\
\pm 9.3\end{array}$ & $\begin{array}{c}254.3 \\
\pm 7.1\end{array}$ & $\begin{array}{l}28.6 \\
\pm 0.5\end{array}$ & $\begin{array}{l}166.3 \\
\pm 4.9\end{array}$ & $\begin{array}{l}53.3 \\
\pm 0.7\end{array}$ & $\begin{array}{l}80.6 \\
\pm 1.7\end{array}$ & $\begin{array}{l}10.3 \\
\pm 0.4\end{array}$ & $\begin{array}{l}1.93 * * \\
\pm 0.03\end{array}$ \\
\hline
\end{tabular}




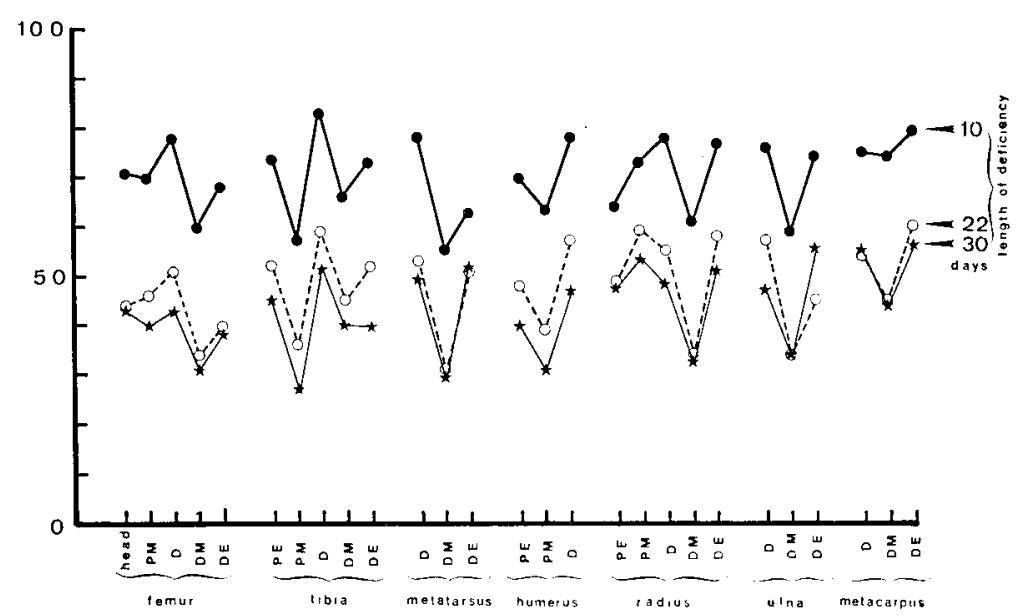

FIG. 3. - Bone $M g$ of magnesium-deficient animals ; level expressed in p. 100 of controls for various parts of limb bone (see fig. 1 for the diagram of bone pieces).

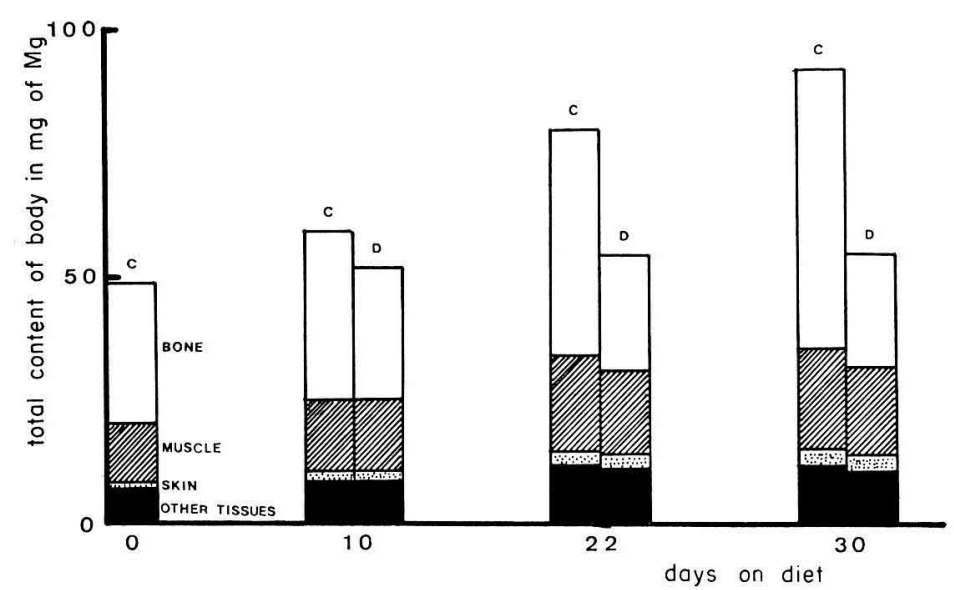

FIG. 4. - Body Mg distribution befween tissues in control or Mg-deficient rats.

calcium increase, and significant phosphorus depletion in many parts of the skeleton. This was especially marked in the metaphysis as it was for $\mathrm{Mg}$ depletion.

Other tissue composition. Magnesium and calcium levels of some tissues (muscle, liver, kidney) on a dry fast-free basis are shown in table 4. Liver magnesium and calcium were not significantly affected. Muscle calcium was not modified but muscle $\mathrm{Mg}$ fell during deficiency. Kidney $\mathrm{Mg}$ was little affected, except at the beginning of the experiment, but heavy calcification occurred.

Gross body composition. These results give an approximation of body weight distribution in control or deficient animals based on the following assumptions : 
- Muscular mass is about 36 p. 100 of body weight in a $100 \mathrm{~g}$ rat and $42 \mathrm{p} .100$ in a $200 \mathrm{~g}$ rat (Miller, 1969); skin weight is 17 p. 100 and from the data of spray and Widdowson (1950) on the total calcium content of the rat, total bone weight is about 9 P. 100 of the body weight.

- Water content of rat body is 76 p. 100 in the muscle (Hamoir, 1961), 60 p. 100 in the skin (Kratzing, 1961), 35 p. 100 in the bone (Eastoe, 1961) and about 80 p. 100 in other tissues.

- The $\mathrm{Mg}$ content in the dry matter is $0.25 / 1000$ in rat skin and about $0.9 / 1000$ in other tissues ; this content remains totally unmodified during $\mathrm{Mg}$ deficiency (Larvor and Rayssiguier, 1971).

- The total skeletal weight is proportional to the limb bone weight.

\section{TABLE 4}

Mognesium and calcium levels (p. 1000 , dry fat free basis), of muscle, liver and kidney during deficiency

\begin{tabular}{|c|c|c|c|c|c|c|c|}
\hline \multirow{2}{*}{$\begin{array}{l}\text { Length of } \\
\text { treatment } \\
\text { (days) }\end{array}$} & \multirow{2}{*}{ Treatment } & \multicolumn{3}{|c|}{ Magnesium } & \multicolumn{3}{|c|}{ Calcium } \\
\hline & & muscle & liver & kidney & muscle & liver & kidney \\
\hline \multirow{2}{*}{10} & Control ... & $1.23 \pm 0.01$ & $0.93 \pm 0.04$ & $1.20 \pm 0.05$ & $0.29 \pm 0.06$ & $0.19 \pm 0.01$ & \pm 0.01 \\
\hline & Mg-deficient & $1.19 * \pm 0.02$ & $0.93 \pm 0.03$ & $1.02 * \pm 0.07$ & $0.24 \pm 0.02$ & $0.16 \pm 0.02$ & $1.30 \pm 0.92$ \\
\hline \multirow{2}{*}{22} & Control & $1.13 \pm 0.04$ & $0.77 \pm 0.03$ & $0.94 \pm 0.05$ & $0.18 \pm 0.07$ & $0.16 \pm 0.02$ & $0.31 \pm 0.02$ \\
\hline & Mg-deficient & $1.04 * \pm 0.02$ & $0.70 \pm 0.03$ & $0.89 \pm 0.05$ & $0.21 \pm 0.03$ & $0.14 \pm 0.01$ & $2.62 * \pm 0.72$ \\
\hline \multirow{2}{*}{30} & Control ... & $1.14 \pm 0.02$ & $0.83 \pm 0.02$ & $0.94 \pm 0.04$ & $0.20 \pm 0.01$ & $0.16 \pm 0.01$ & \pm 0.01 \\
\hline & Mg-deficient . & $1.09 \pm 0.06$ & $0.86 \pm 0.02$ & $1.05 \pm 0.06$ & $0.23 \pm 0.01$ & $0.18 \pm 0.02$ & $3.01 * * \pm 0.26$ \\
\hline
\end{tabular}

If we accept these assumptions and data, body $M g$ is distributed as shown in figure 4 during $\mathrm{Mg}$ deficiency in growing rats. The total body $\mathrm{Mg}$ remains practically constant ; there is considerable $\mathrm{Mg}$ transfer from the bone to other tissues and a light decrease in muscle $\mathrm{Mg}$. When bone $\mathrm{Mg}$ is exhausted at about 22 days in our conditions, it is impossible for the organism to make new tissues with a lower $\mathrm{Mg}$ content, growth is inhibited (table 1).

Effect of $M g$ deficiency on bone matabolism. The present results confirm the impairment of bone metabolism during $\mathrm{Mg}$ deficiency. If the correlations between urinary hydroxyprolin, plasma $\mathrm{Mg}$ bone $\mathrm{Mg}$ are computed, the following results are obtained :

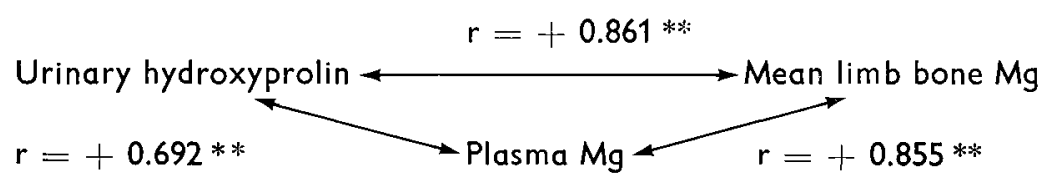

But if partial correlation coefficients are computed (correlation coefficient between two factors, the third being considered as constant), the results become : 


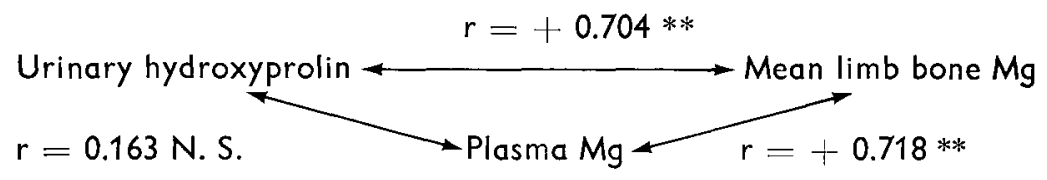

This suggests that $\mathrm{Mg}$ deficiency being the primordial factor, the drop in urinary hydroxyprolin is not the result of lower plasma $\mathrm{Mg}$, but of lower bone $\mathrm{Mg}$.

\section{Discussion.}

Bone as a $\mathrm{Mg}$ store. Bone appears as the main, if not the only, $\mathrm{Mg}$ store. The fast decrease in metaphysis $\mathrm{Mg}$ results from the very short life of this part of the bone and is due to the disappearance of high $\mathrm{Mg}$ bone and the synthesis of new low $\mathrm{Mg}$ bone. These processes are less important in the other bone parts and the physical Mg exchange between bone and plasma is probably the main factor then. In the $\mathrm{Mg}$ deficient rat, $\mathrm{Mg}$ is strongly retained by the organism. The dilution of $\mathrm{Mg}$ in the new tissues of young growing animals is the principal cause for tissue $\mathrm{Mg}$ drop, and it explains the differences observed in deficiency, which evolves faster in young than in adult rats (Smith and Field, 1963 ; Hunt, 1971). This may not be the case in other species such as cattle, where $\mathrm{Mg}$ deficiency appears more dramatic in adults (Rook, 1963) than in calves (Blaxter, Rook and MacDonald, 1954), perhaps because adult bone has very poor $\mathrm{Mg}$ exchange ability.

$\mathrm{Mg}$ deficiency and calcium metabolism. Hypercalcemia during magnesium deficiency is specific for the rat, most species being severely hypocalcemic in the same conditions.

Bone catabolism decreases in all species, as confirmed in this report by urinary hydroxyprolin decline. The particularity of the rat (hypercalcemia) has been ascribed by MacManus and Heaton (1969) to the very high ability of this species to assimilate calcium, together with a classical increase in calcium digestibility during magnesium deficiency.

The increase in bone weight still remains to be explained. It was significant only after 22 days of deficiency, when the decrease in urinary hydroxyprolin became evident; the increase in bone weight might result in the diminished bone catabolism with a normal accretion. This is confirmed by the fact that there was an especially large weight increase in the most active parts of the bone in which Mg loss was highest. Many hypotheses have been proposed to explain the decrease in bone catabolism. Bones are less sensitive to PTH and to vitamin D metabolites during $\mathrm{Mg}$ deficiency (Reddy et al., 1973 ; Rayssiguier, Aygbede and Miravet, 1974 ; Rayssiguier ef al., 1975). After PTH or vitamin D injection in some experiments (Rayssiguier and Larvor, 1974 ; Miravet ef al., 1976), serum calcium is the same in Mg-deficient animals as in the controls, but as the calcium pool decreases during $\mathrm{Mg}$ deficiency (Larvor and Labat, 1978), a lower calcium release is needed to produce the same increase in serum calcium. In addition it has been suggested that there is a lack of parathyroid gland response to the drop in plasma calcium in $\mathrm{Mg}$-deficient rats (Rayssiguier and Larvor, 1974) and calves (Rayssiguier et al., 1977) and no change in calcitonin secretion. 
The increase in bone weight and the decrease in urinary hydroxyprolin are suggestive of a decreased collagenolytic acitivity with an increase in bone organic constituents. Bone refractoriness to PTH and to vitamin D might be related to the effect of $\mathrm{Mg}$ deficiency on bone proteic matrix (the decrease of collagen breakdown could inhibit bone catabolism). No reports in the literature refer to the effect of $\mathrm{Mg}$ upon bone collagenolytic activity. However it has been documented that $\mathrm{Mg}$ deficiency inhibits the release of collagenolytic activity from the uterus (Rayssiguier, Badinand and Kopp, 1977). More experimental work would be required to elucidate the nature of the changes in bone organic constituents.

Réunion Groupe Développement INRA/Productions animales Montpellier, 17-18 mai 1977.

Acknowledgements. - The authors are indebted to Mr. J. Kopp, Station d'Etudes sur la Viande, I.N.R.A., Theix, for the estimation of hydroxyprolin in urine, and to Dr. M. Juster, Laboratoire de Microradiographie, C.N.R.S. for valuable discussion. The technical assistance of Mr. Genest is greatly appreciated.

Résumé. 1. La carence en magnésium a été produite chez des rats Sprague Dawley mâles en alimentation appariée avec celle des témoins. Les animaux ont été sacrifiés à 10 , 22 ou 30 jours de traitements.

2. La composition plasmatique des carencés se caractérisait par : hypomagnésémie, légère hypercalcémie, hypophosphatémie, glycémie normale. L'hydroxyproline urinaire diminuait chez les carencés après 21 et 29 jours de carence.

3. Les os des membres furent fragmentés selon le schéma de la figure 1. Leur teneur en magnésium était fortement diminuée, et leur poids accru ; ces deux modifications étaient surtout importantes dans la métaphyse, moyennes dans l'épiphyse et plus faible dans la diaphyse.

4. Les modifications de la composition de quelques tissus et de l'ensemble du corps sont décrites.

5. La baisse du catabolisme osseux paraît liée principalement à la baisse du magnésium osseux (et non au magnésium plasmatique). L'augmentation du poids de l'os paraît résulter de la diminution du catabolisme. L'interprétation des modifications du métabolisme calcique est discutée.

\section{References}

BELANGER L. F., 1958. Quantitative appreciation by comparative autoradiography of the synthesis and maintenance of some organic constituents of the epiphyseal plate of growing rats, in relation with magnesium deficiency. J. Histochem. Cytochem., 6, 146-153.

BERGMAN I., LOXLEY R., 1963. Two improved and simplified methods for the spectrophotometric determination of hydroxyproline. Anal. Chem., 35, 1961-1965.

BLAXTER K. L., ROOK J. A. F., MacDONALD A. M., 1954. Experimental magnesium deficiency in calves. I. Clinical and pathological observations. J. comp. Path., 64, 157-175.

CARTIER P., PICARD J., 1955. La minéralisation du cartilage ossifiable. II. Le système ATP asique du cartilage. Bull. Soc. Chim. biol., 37, 661-675.

EASTOE J. E., 1961. The chemical composition of bone, 715-720. In LONG C. Biochemists' Handbook. E. and F. N. Spon, London.

FORBES R. M., 1964. Mineral utilization in the Rat. II. Restoration of normal tissue levels of magnesium and calcium following magnesium deficiency. J. Nutr., 83, 44-48.

HAMOIR G., 1961. Chemical composition of muscle, p. 666-673. In LONG C. Biochemist's Handbook, E. and F. N. Spon London. 
HJERPE C. A., 1968. Influence of dietary magnesium on metabolism of calcium and magnesium in sheep. Amer. J. vet. Res., 29, 143-151 ; 2307-2314.

HUNT B. J., 1971. Age and magnesium deficiency in the rat whith emphasis on bone and muscle magnesium. Amer. J. Physiol., 221, 1809-1817.

KRATZING C. C., 1961. Metabolic rates for slices of animal tissues, p. 795-810. In LONG C. Biochemist's Handbook, E. and F. N. Spon, London.

LARVOR P., GIRARD A., BROCHART M., 1964. Etude de la carence expérimentale en magnésium chez le veau. II. Interférence entre la carence en magnésium et le métabolisme du calcium. Ann. Biol. anim. Bioch. Biophys., 4, 371-382.

LARVOR P., RAYSSIGUIER Y. 1971. Influence de la démédullation surrénalienne sur le métabolisme du magnésium au cours de la carence en cef élément chez le rat. C. R. Acad. Sci. Paris, Sér. $D, 273,1408-1410$.

LARVOR P., LABAT M. L., 1978. The influence of magnesium deficiency on calcium metabolism in the rat. Ann. Biol. anim. Bioch. Biophys., 18, 149-155.

MacMANUS J., HEATON F. W., 1969. The effect of magnesium deficiency on calcium homeostasis in the rat. Clin. Sci., 36, 297-306.

MaCMANUS J., HEATON F. W., LUCAS P. W., 1971. A decreased response to parathyroid hormone in magnesium deficiency. J. Endocr., 49, 253-258.

MICHEL M. C., 1971. Analyse quantifative de quelques substances azotées ef glucidiques en milieu biologique. Essai de rationalisation. Thèse Doct. Univ., Clermont-Ferrand.

MILLER S. A., 1969. Protein metabolism during growth and development, 183-223. In MUNRO, H. N. Mammalian protein metabolism, vol. 3, Acad. Press, New York, London.

MIRAVET L., AYGBEDE O., CARRE M., RAYSSIGUIER Y., LARVOR P., 1976. Lack of vitamine D action on serum calcium in magnesium-deficient rats. 2nd Int. Symp. Magnesium, Montreal.

NIELSEN S. P., 1973. Effect of magnesium on calcification on young bone in tissue culture. Calcif. Tiss. Res., 11, 78-94.

ORENT E. R., KRUSE H. D., MCCOLLUM E. V., 1934. Studies on magnesium deficiency in animals. VI. Chemical changes in the bone with associated blood changes resulting from magnesium deprivation. J. biol. Chem., 106, 573-593.

PAK C. Y. C., DILLER E. C., 1969. Ionic interaction with bone mineral. V. Effect of magnesium, citrate, fluoride and sulfate on the solubility, dissolution and growth of bone mineral. Calcif. Tiss. Res., 4, 69-77.

RAISZ L. G., NIEMANN I., 1969. Effect of phosphate, calcium and magnesium on bone resorption and hormonal responses in tissue culture. Endocrinology, 85, 446-452.

RAYSSIGUIER Y., AYGBEDE O., MIRAVET L., 1974. Métabolisme et activité du cholécalciférol et de quelques dérivés hydroxylés chez le rat. Ann. Biol. anim. Bioch. Biophys., 14, 829-835.

RAYSSIGUIER Y., LARVOR P., 1974. Parathyroid response to hypocalcemia in magnesium deficient rat. Horm. Metab. Res., 6, 91.

RAYSSIGUIER Y., CARRE M., AYGBEDE O., MIRAVET L., 1975. Activité du 1-25 dihydroxycholécalciférol chez le rat carencé en magnésium. C. R. Acad. Sci., Paris, Série D, 281, 731-734.

RAYSSIGUIER Y., BADINAND F., KOPP J., 1977. Effect of magnesium deficiency on parturition and uterine involution in the rat (in press).

RAYSSIGUIER Y., GAREL J. M., DAVICCO M. J., BARLET J. P., 1977. Parathyroid hormone and calcitonin in magnesium-deficient calves. Horm. Metab. Res., 9, 438-439.

REDDY C. R., COBURN J. W., HARTEBOWER D. L., FRIEDLER R. M., BRICKMAN A. S., MASSRY S. G., JOWSEY J., 1973. Studies on mechanism of hypocalcemia of magnesium depletion. J. clin. Invest., 52. 3000-3010.

ROOK J. A. F., 1963. Experimental magnesium deficiency in the cow. J. comp. pathol. Therap., 73, 93-97.

SMITH B. S. W., FIELD A. C., 1963. Effect of age on magnesium deficiency in rats. Brit. J. Nutr., 17, $591-600$.

SMITH R. H., 1959. Calcium and magnesium metabolism in calves. 4. Bone composition in magnesium deficiency and the control of plasma magnesium. Biochem. J., 72, 609-614.

SPRAY C. M., WIDDOWSON E. M., 1950. The effect of growth and development on the composition of mammals. Brit. J. Nutr., 4, 332-353.

WATCHORN E., MCCANCE R. A., 1937. Subacute magnesium deficiency in rats. Biochem. J. 31, 1379-1390. 